mgr inz. Krzysztof Przepióra

mgr inz. Patryk Szuberski

Instytut Pojazdów Szynowych ,,TABOR”

\title{
Tram braking systems research in view of tram vehicle type approval tests
}

\section{Badania układów hamulcowych pojazdów tramwajowych w aspekcie homologacji typu tramwajów}

\begin{abstract}
The article presents the current legislation in the field of braking system testing in the tram vehicles type approval process. The currently used construction solutions of brake systems in tram vehicles are shown and discussed. The necessary test range and inspection of the braking system during the type approval tests, depending on the date of manufacture of the tram and its destination, are also outlined. This article provides justification for extending the scope of braking systems testing during the type approval process which is currently not required by any applicable law.

Artykut przedstawia obecnie obowiazujace przepisy prawne $w$ aspekcie badań uktadów hamulcowych $w$ procesie homologacji typu tramwajów. Przedstawia stosowane obecnie rozwiazania konstrukcyjne układów hamulcowych w pojazdach tramwajowych. Wymienia konieczny zakres prób i sprawdzeń układu hamulcowego, podczas badań homologacyjnych, w zależności od daty produkcji tramwaju oraz jego przeznaczenia. Artykut przedstawia uzasadnienie rozszerzenia zakresu badań układów hamulcowych $w$ procesie homologacji, które obecnie nie sq wymagane obowiazujacymi przepisami prawnymi.
\end{abstract}

\section{LEGAL BASIS FOR TESTING THE BRAK- ING SYSTEMS OF TRAMS}

At present, carrying out tram type-approval tests is regulated in Poland by the Declaration of the Minister of Transport, Construction and Maritime Economy of 28 May 2013 concerning the typeapproval of trams and trolleys (Journal of Laws, 2015, item 38) [1]. The scope and method of carrying out type approval tests as well as the detailed method of carrying out type approval procedures are set out in point 2 (1) of Annex 2 to the said Regulation. The technical conditions that vehicles such as trams and trolleybuses taking part in road traffic should meet and the scope of their necessary equipment are set out in the Ordinance of the Minister of Infrastructure of 2 March 2011 on technical conditions of trams and trolleybuses and their key equipment (Journal of Laws 2011 No. 65 item 344) [2], whereas the scope and method of carrying out tests of tram vehicles is included in the Regulation of the Minister of Infrastructure of 28 January 2011 on the scope, conditions, dates and manner of carrying out technical tests of trams and trolleybuses and the facilities that carry out these tests (Journal of Laws 2011 No. 65 item 343) [3].

In the light of the abovementioned regulations, the tram is defined as a vehicle intended for the transport of passengers or goods moving on rails on public

\section{PODSTAWA PRAWNA DOTYCZACA BA- DAŃ UKLADÓW HAMULCOWYCH PO- JAZDÓW TRAMWAJOWYCH}

W chwili obecnej w Polsce kwestię przeprowadzania badań homologacyjnych typu tramwaju reguluje Obwieszczenie Ministra Transportu, Budownictwa i Gospodarki Morskiej z dnia 28 maja 2013 r. w sprawie homologacji typu tramwajów i trolejbusów (Dz. U. 2015 poz. 38) [1]. Zakres i sposób przeprowadzania badań homologacyjnych typu jak i szczegółowy sposób przeprowadzania procedur homologacji typu zapisano w pkt 2 ppkt 1 załącznika $\mathrm{Nr} 2$ do wymienionego rozporządzenia. Warunki techniczne pojazdów, jakim powinny odpowiadać tramwaje i trolejbusy uczestniczące w ruchu drogowym oraz zakres ich niezbędnego wyposażenia zapisano w Rozporządzenie Ministra Infrastruktury z dnia 2 marca 2011 r. w sprawie warunków technicznych tramwajów i trolejbusów oraz zakresu ich niezbędnego wyposażenia (Dz.U. $2011 \mathrm{nr} 65$ poz. 344) [2], natomiast zakres i sposób przeprowadzenia badań pojazdów tramwajowych zamieszczono w Rozporządzeniu Ministra Infrastruktury z dnia 28 stycznia 2011 r. w sprawie zakresu, warunków, terminów i sposobu przeprowadzania badań technicznych tramwajów i trolejbusów oraz jednostek wykonujących te badania (Dz.U. $2011 \mathrm{nr} 65$ poz. 343) [3]. 
roads, and powered by electricity. Basically, the trams are divided in directional terms as one-way and twoway types.

The further division is based on the vehicle equipment in drive systems and to the driver position, i.e. the motor tramcar (equipped with the main drive system and the driver's seat), an active tramcar (equipped with a drive system and intended for connection with at least one motor tramcar), passive tramcar (not equipped with a drive system and designed to be connected to at least one motor tramcar).

Tram vehicles have been divided based on the distribution of passenger space, into multi-section vehicles (consisting of at least two units connected in a way that allows the passengers to freely move between the units) and tram units (consisting of at least two trams connected via a coupler, without the possibility of passengers crossing between vehicles). In addition to passenger trams, technical trams (for the maintenance, and repair of the technical infrastructure) and passive technical trams (without propulsion machinery, which are to be connected to technical trams) can also be distinguished.

Regarding the tram vehicles braking systems the legislator has divided the braking systems in the Journal of Laws 2011 No. 65 item 344 in Chapter 8 [2] as follows:

- $\quad$ service brake - designed to reduce the tram speed and stop it reliably, quickly and efficiently, regardless of the speed and load and the angle of climb or fall of the track (road), with the possibility of adjusting the braking intensity;

- secondary brake - used to stop the tram in the event of a service brake failure; This brake should use braking independent of the grip between the wheel and the rail;

- mechanical parking brake - used to immobilize the tram while stationary; it is permissible to replace this brake with another device which allows permanent and reliable immobilization of the tram after its stop. The brake should be designed so that it cannot be released automatically and be clearly marked for the actuation direction in the case of a manual drive;

- emergency brake - used to stop the tram by the passenger in the event of a safety hazard;

According to Annex 6, point 7 of the Journal of Laws 2015 item 38 [1] the types of brakes that may be used for the above braking systems are as follows:

- electrodynamic brake,

- passive or active mechanical brake,

- track brake.

\section{TYPES OF BRAKING SYSTEMS USED IN TRAM VEHICLES}

As mentioned earlier in accordance with the provisions of Journal of Laws 2015 item 38 [1] currently approved in Poland tram vehicles must be
W świetle przytoczonych rozporządzeń tramwaj jest zdefiniowany jako pojazd przeznaczony do przewozu osób lub rzeczy, poruszający się po szynach na drogach publicznych, który zasilany jest energią elektryczną. Zasadniczo tramwaje podzielono pod względem przystosowania do kierunku jazdy na jednokierunkowe i dwukierunkowe.

Dalszy podział wynika z wyposażenia pojazdu $\mathrm{w}$ urządzenia napędowe oraz $\mathrm{w}$ stanowisko motorniczego tj. tramwaj silnikowy (wyposażony w urządzenia napędowe i stanowisko motorniczego), tramwaj doczepny czynny (wyposażony w urządzenia napędowe i przeznaczony do łączenia z przynajmniej jednym tramwajem silnikowym), tramwaj doczepny bierny (niewyposażony $\mathrm{w}$ urządzenia napędowe i przeznaczony do łączenia z przynajmniej jednym tramwajem silnikowym).

Ze względu na podział przestrzeni pasażerskiej pojazdy tramwajowe podzielono na wieloczłonowe (składające się z przynajmniej dwóch członów połączonych przegubem w sposób umożliwiający przechodzenie osób między członami) oraz na zespoły tramwajowe (składające się z przynajmniej dwóch tramwajów połączonych sprzęgiem, bez możliwości przechodzenia osób między pojazdami). Oprócz tramwajów osobowych wyróżniamy tramwaje techniczne (przeznaczone do obsługi, naprawy i utrzymania infrastruktury technicznej) oraz tramwaje doczepne bierne techniczne (nieposiadające urządzeń napędowych, przeznaczone do łączenia z tramwajami technicznymi).

W przypadku układów hamulcowych pojazdów tramwajowych w Dz.U. $2011 \mathrm{nr} 65$ poz. $344 \mathrm{w}$ Rozdziale 8 [2] ustawodawca dokonał podziału systemów hamowania wg następującego porządku:

- hamulec roboczy - służący do zmniejszania prędkości tramwaju i zatrzymania go w sposób niezawodny, szybki i skuteczny, niezależnie od prędkości i obciążenia oraz od kąta wzniesienia lub spadku torów (drogi), z możliwością regulacji intensywności hamowania;

- hamulec awaryjny - służący do zatrzymania tramwaju w razie awarii hamulca roboczego; hamulec ten powinien wykorzystywać hamowanie niezależne od przyczepności między kołem i szyną;

- hamulec postojowy mechaniczny - służący do unieruchamiania tramwaju podczas postoju; dopuszcza się zastapienie tego hamulca innym urządzeniem pozwalającym na trwałe i niezawodne unieruchomienie tramwaju po jego zatrzymaniu; hamulec ten powinien być tak skonstruowany, aby niemożliwe było jego samoczynne zwolnienie, oraz mieć wyraźne oznakowanie kierunku uruchamiania $\mathrm{w}$ przypadku napędu ręcznego; 
equipped with the following types of brakes: electrodynamic, mechanical and track (except technical trams). The use of each of those brakes is determined primarily by legal requirements, and subsequently regulated by constructional, economic, and future tram user requirements.

\section{Electrodynamic brake}

The electrodynamic brake is the basic type of tram brake in newly built and modernized vehicles. It is used primarily for the service brake system as well as for emergency braking. The electrodynamic system utilizes the ability to switch the traction motors from generating momentum to generating electric current and thus convert the kinetic energy of a moving vehicle into electric power. In the tram vehicles electrodynamic braking system the energy produced by the braking process is lost in the braking resistor or is returned to the overhead contact line. Also increasingly common in trams is the use of ultracapacitors to be charged with braking energy, which is then used for the vehicle start, as well as in driving conditions when without catenary.

\section{Mechanical brake}

Tram vehicles use passive and active mechanical brakes. Passive brakes are hydraulically or electrically controlled. In either case, the working element is a spring which, through the braking mechanism, pushes the brake linings against the disc or the brake drum. In hydraulic systems, the reduction of the tram braking power is achieved by applying hydraulic pressure to the brake mechanism, which counteracts the force exerted by the spring. In electrical systems, the reduction of the tram braking power is achieved by properly supplying the electrical coil of the brake mechanism with electric energy and thereby generating an electromagnetic field that counteracts the spring brake force. Passive mechanical brakes can be operated in a binary mode, i.e. braking and loose, as well as continuous mode, i.e. the braking force can be adjusted proportionally to the pressure value in the brake cylinder, from the maximum value to the braking state. In passive brakes, a lack of pressure in the hydraulic system or voltage in the electrical system of the brake caused by the fault of the brake system automatically leads to the self-braking of the tram.

The active mechanical brakes of the tram vehicles are the hydraulic brakes applied on the rolling carriages. The principle of their operation is the opposite of passive brakes. The braking force increases proportionally to the hydraulic pressure supplied to the brake mechanism. Brake release takes place when the hydraulic pressure is reduced and the return spring is active, this spring also keeps the unit brakes in a released state. Active brakes are used for sudden emergency braking, and also to support electrodynamic brakes.
- hamulec bezpieczeństwa - służący do zatrzymywania tramwaju przez pasażera $\mathrm{w}$ razie zagrożenia bezpieczeństwa;

- hamulec nagły - służący do zatrzymywania tramwaju z największym możliwym do uzyskania opóźnieniem hamowania w sytuacji wystąpienia zagrożenia.

Zgodnie z załącznikiem 6, pkt 7 do Dz. U. 2015 poz. 38 [1] rodzaje hamulców, jakie mogą brać udział $\mathrm{w}$ trakcie aktywowania ww. systemów hamowania są następujące:

- hamulec elektrodynamiczny,

- hamulec mechaniczny pasywny lub aktywny,

\section{RODZAJE UKLADÓW HAMULCOWYCH STOSOWANE W POJAZDACH TRAMWA- JOWYCH}

Jak wspomniano wcześniej zgodnie z zapisami w Dz. U. 2015 poz. 38 [1] obecnie homologowane w Polsce pojazdy tramwajowe muszą zostać wyposażone w następujące rodzaje hamulców: elektrodynamiczny, mechaniczny i szynowy (wyjątek tramwaje techniczne). Zastosowanie każdego $\mathrm{z}$ nich jest sankcjonowane przede wszystkim wymogami prawnymi, a w dalszej kolejności regulowane względami konstrukcyjnymi, ekonomicznymi oraz wymaganiami przyszłego użytkownika tramwaju.

\section{Hamulec elektrodynamiczny}

Hamulec elektrodynamiczny w nowobudowanych i modernizowanych konstrukcjach stanowi podstawowy rodzaj hamulca tramwajowego. Jest on wykorzystywany przede wszystkim dla sytemu hamowania roboczego, a także w hamowaniach nagłych i bezpieczeństwa. Układ elektrodynamiczny wykorzystuje możliwość przełączenia silników trakcyjnych z pracy trakcyjnej do pracy prądnicowej i tym samym zamianę energii kinetycznej poruszającego się pojazdu na energię elektryczna. W elektrodynamicznych układach hamulcowych pojazdów tramwajowych wytworzona $\mathrm{w}$ procesie hamowania energia zostaje wytracona $\mathrm{w}$ rezystorach hamowania lub jest zwracana do sieci trakcyjnej. Również coraz częstszym rozwiązaniem w tramwajach jest zastosowanie superkondensatorów ładowanych energia wytworzoną przy hamowaniu, która jest wykorzystana przy rozruchu pojazdu, także w warunkach jazdy bez sieci trakcyjnej.

\section{Hamulec mechaniczny}

W pojazdach tramwajowych maja zastosowanie hamulce mechaniczne pasywne i aktywne. Hamulce pasywne są sterowane hydraulicznie lub elektrycznie. W obu przypadkach elementem roboczym jest sprężyna, która za pośrednictwem mechanizmu hamulcowego w stanie zahamowania wywołuje docisk okładzin hamulcowych do tarczy lub bębna hamulcowego. W układach hydraulicznych zmniejszenie siły hamowania tramwaju odbywa się przez doprowadzenie ciśnienia hydraulicznego do mechanizmu hamulcowego, które- 


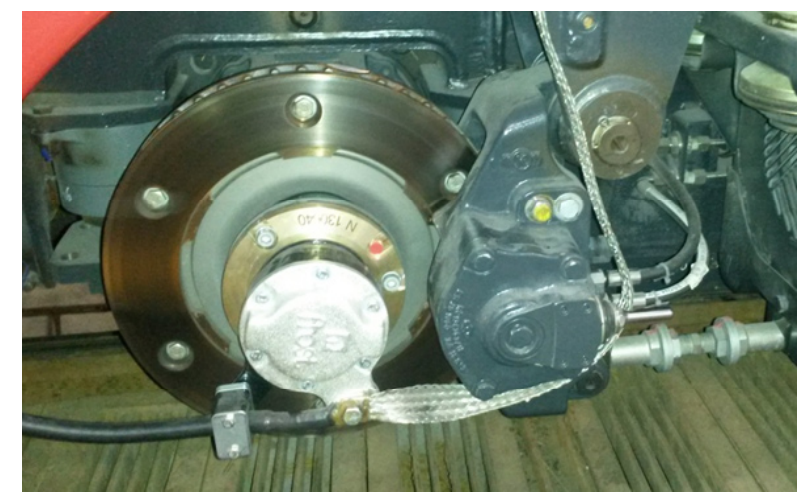

Rys. 1 - Mechaniczny hamulec pasywny tarczowy typu HSE1P28F Fig. 1 - Passive mechanical brake disc type HSE1P28F

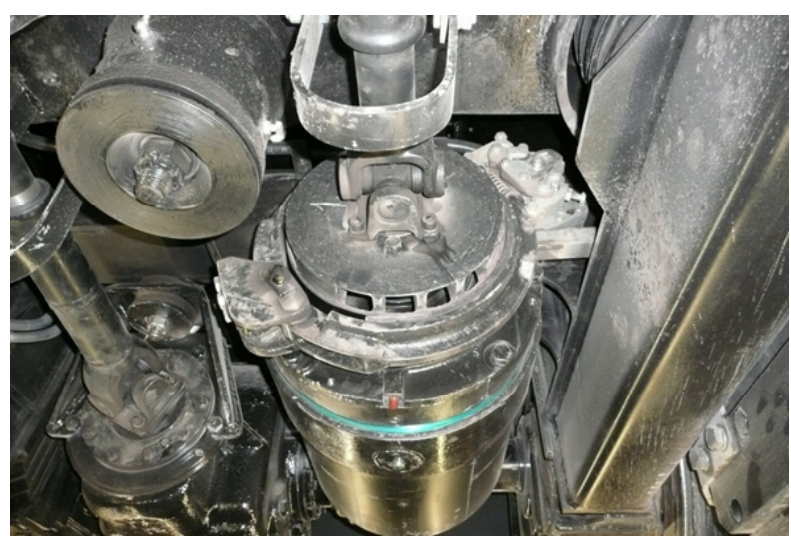

Rys. 2 - Mechaniczny hamulec pasywny bębnowy typu ZU-01/060,00

Fig. 2 - Passive mechanical brake drum type ZU01/06-0,00

The active mechanical brakes of the tram vehicles are the hydraulic brakes applied on the rolling carriages. The principle of their operation is the opposite of passive brakes. The braking force increases proportionally to the hydraulic pressure supplied to the brake mechanism. Brake release takes place when the hydraulic pressure is reduced and the return spring is active, this spring also keeps the unit brakes in a released state. Active brakes are used for sudden emergency braking, and also to support electrodynamic brakes.

The mechanical brakes fitted on the trailer bogies of tram vehicles serve as service brakes, while in the case of motor bogies, they are complementary in the absence of sufficient braking force of the electrodynamic service brakes, or they take over the braking function in the event of a mechanical failure. Mechanical brakes are fitted with anti-skid systems to protect the wheels of the vehicle against locking at reduced wheel/rail grip. They also function as a parking brake when the vehicle is stopped, for example at a stop.

\section{Track brake}

The track brakes of tram vehicles fulfill the function of a braking system independent of the grip between the wheel and the rail as required by the law. go układ przeciwdziała sile wywieranej przez sprężynę. W układach elektrycznych zmniejszenie siły hamowania tramwaju odbywa się przez odpowiednie zasilenie cewki elektrycznej luzownika mechanizmu hamulcowego i tym samym wytworzenie pole elektromagnetycznego przeciwdziałającego sile sprężyny hamulcowej. Mechaniczne hamulce pasywne mogą pracować w sposób dwustanowy, tzn. stan zahamowany i stan odhamowany lub bezstopniowo, tzn. siła hamowania może być regulowana proporcjonalnie od wartości ciśnienia w cylindrze hamulcowym, od wartości maksymalnej do stanu odhamowania. W hamulcach pasywnych brak ciśnienia w układzie hydraulicznym lub napięcia w układzie elektrycznym hamulca spowodowany usterką wdraża samoczynnie hamowanie tramwaju.

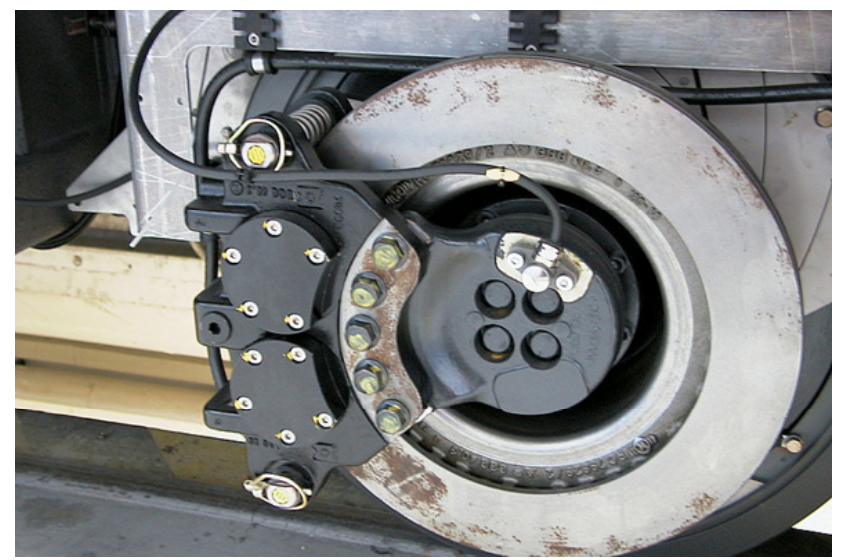

Rys. 3 - Mechaniczny hamulec aktywny tarczowy typu HYA 26/50 [7]

Fig. 3 - Active mechanical brake disc type HYA 26/50 [7]

Mechaniczne hamulce aktywne pojazdów tramwajowych są hamulcami hydraulicznymi stosowanymi na wózkach tocznych. Zasada ich działania jest odwrotna do hamulców pasywnych. Siła hamowania wzrasta proporcjonalnie do ciśnienia hydraulicznego dostarczanego do mechanizmu hamulcowego. Odhamowanie hamulca odbywa się przy obniżeniu ciśnienia hydraulicznego oraz wskutek działania sprężyny powrotnej, która również utrzymuje zespół w stanie odhamowanym. Hamulce aktywne wykorzystywane są przy hamowaniach nagłych, awaryjnych, a także wspomagają hamowanie elektrodynamiczne.

W pojazdach tramwajowych hamulce mechaniczne zabudowane na wózkach tocznych pełnią funkcję hamulca roboczego, natomiast w przypadku wózków napędowych pełnią funkcję uzupełniającą przy braku wystarczającej siły hamowania hamulca elektrodynamicznego dla hamowania roboczego lub przejmują całkowicie funkcję hamowania w przypadku jego awarii. Hamulce mechaniczne wyposażane są w układy przeciwpoślizgowe zabezpieczające koła pojazdu przed zablokowaniem przy obniżonej przyczepności koło/szyna. Pełnią też funkcję hamulca trzymającego w chwili zatrzymania pojazdu np. na przystanku, a także funkcję hamulca postojowego. 
They are built as rigid beams suspended from the springs at a height of up to a dozen millimeters above the rail. During braking, the excitation current flowing through the electromagnetic coils generates a magnetic field that causes the track brake beam to be pulled towards the rail and thus produces a braking force. The track brakes are mounted on trailer and motor bogies and are used for emergency braking only. Track brakes are also used in the case of braking systems failure to ensure their readiness to operate even in the event of an overhead catenary power failure. They are powered by the vehicle batteries directly.

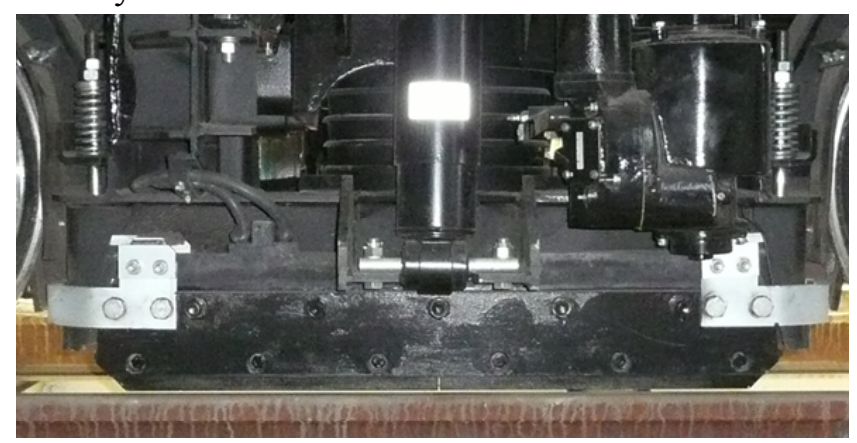

Fig. 4 - Track brake type HS-6/24

Rys. 4 - Hamulec szynowy typu HS-6/24

3 THE SCOPE OF REQUIRED TRAM BRAKING SYSTEMS TESTING FOR TYPE APPROVAL TESTS

The scope of braking systems tests which are necessary in the type approval process for trams in Poland is determined by the Journal of Laws 2015 item 38 [1].

The most basic test for braking systems is the measurement of the braking distance required for the vehicle to come to a halt when moving at $30 \mathrm{~km} / \mathrm{h}$ for each of the brake systems: service, secondary, and emergency.

The methodology and conditions of the test, as well as the criteria to be fulfilled by the braking system, are set out in the Journal of Laws 2011 No. 65 item 343 [3]. According to Annex 2 of the said Regulation, both tram units and multi-section vehicles consisting of a motor bogey and active or passive bogeys must all be subjected to the brake tests.

As mentioned previously, the braking performance is confirmed by measuring the braking distance at the speed of $30 \mathrm{~km} / \mathrm{h}$ (according to the vehicle speedometer). For these brakes, it is also necessary to determine the value of the brake delay, which is calculated from the vehicle initial speed and the resulting braking distance, assuming the linear deceleration. Testing the braking performance only on the basis of the measurement of the braking delay is also permitted. During the tests the tram cannot be loaded.

The Regulation specifies the following environmental conditions during the test: the test track

\section{Hamulec szynowy}

Hamulce szynowe pojazdów tramwajowych pełnią funkcję wymaganego przepisami hamulca niezależnego od współczynnika przyczepności między kołem a szyną. Zbudowane są jako sztywne belki zawieszone sprężyście na wysokości do kilkunastu milimetrów nad szyną tramwajowa. Podczas hamowania prąd wzbudzenia płynący w cewkach elektromagnetycznych wytwarza pole magnetyczne powodujące przyciagnięcie hamulca szynowego do szyny i tym samym wytworzenie siły hamowania. Hamulce szynowe montowane są na wózkach napędnych oraz tocznych i używane są przy hamowaniach nagłych i bezpieczeństwa. Hamulce szynowe są również wykorzystywane w stanach awaryjnych układu hamulcowego, by zapewnić ich gotowość do pracy nawet w przypadkach stanu awaryjnego sieci trakcyjnej. Zasilane są bezpośrednio $\mathrm{z}$ akumulatorów pojazdu.

\section{ZAKRES BADAŃ KONIECZNYCH UKLA- DÓW HAMULCOWYCH DLA BADAŃ HO- MOLOGACYJNYCH tramwajów}

Zakres badań układów hamulcowych, których przeprowadzenie jest konieczne $\mathrm{w}$ procesie homologacji tramwajów w Polsce ustala Dz. U. 2015 poz. 38 [1].

Podstawowym badaniem jest pomiar długości drogi hamowania z prędkości $30 \mathrm{~km} / \mathrm{h}$ dla systemów hamowania: roboczego, nagłego, bezpieczeństwa oraz awaryjnego.

Metodykę oraz warunki prowadzenia badań, a także kryteria, jakie powinien spełnić układ hamulcowy zostały zapisane w Dz.U. $2011 \mathrm{nr} 65$ poz. 343 [3]. Zgodnie $\mathrm{z}$ załącznikiem 2 wymienionego rozporządzenia badaniom hamulca poddane muszą zostać zarówno tramwaje pojedyncze, jak i zespoły tramwajowe złożone $\mathrm{z}$ wagonu silnikowego oraz wagonów doczepnych czynnych lub biernych.

Jak wspomniano wcześniej skuteczność hamowania potwierdza się na podstawie pomiaru drogi hamowania z prędkości $30 \mathrm{~km} / \mathrm{h}$ (według wskazań prędkościomierza wagonu). Dla hamowań tych konieczne jest także wyznaczenie wartości opóźnienia, którą wylicza się z prędkości rozpoczęcia hamowania i uzyskanej drogi hamowania przy założeniu ruchu jednostajnie opóźnionego. Dopuszcza się również badanie skuteczności hamowania jedynie na podstawie pomiaru samego opóźnienia hamowania. W trakcie prób tramwaj nie może być obciążony.

Rozporządzenie określa następujące warunki środowiskowe podczas badań: odcinek torów, na których prowadzone są czynności badawcze ma być wolny od zagrożeń dla bezpieczeństwa ruchu oraz powinien być prosty i poziomy, a szyny czyste i suche. Skuteczność hamowania tramwaju uznawana jest za wystarczająca, jeżeli droga i opóźnienie hamowania nie przekroczy wartości dopuszczalnych zależnych od rodzaju hamowania oraz daty produkcji pojazdu (patrz 
section shall be free from traffic safety hazards and shall be straight and horizontal and the rails clean and dry. Tram stop effectiveness is considered sufficient if the braking distance and deceleration do not exceed the limit values depending on the type of braking and the date of vehicle production (see Table 1).

In the case of tram assemblies consisting of a motor bogey and trailer bogeys, the braking distance may not exceed $20 \%$ of the values given in Table 1 , and in the case of a tram unit complex made up of wagons produced in different years, it must not be longer than the distance specified for the oldest vehicle. tabela 1).

W przypadku zespołów tramwajowych złożonych $\mathrm{z}$ wagonu silnikowego i wagonów doczepnych biernych dopuszcza się wydłużenie drogi hamowania nie więcej niż o $20 \% \mathrm{w}$ stosunku do wartości podanych w tabeli 1 , a w przypadku zespołu tramwajowego złożonego $\mathrm{z}$ wagonów wyprodukowanych $\mathrm{w}$ różnych przedziałach czasowych dopuszcza się, aby droga hamowania była nie dłuższa niż dla pojazdu starszego.

Tabela 1 - Maksymalne długości dróg oraz opóźnień hamowania w odniesienia do rodzaju hamowania oraz daty produkcji tramwaju

Table 1 - Maximum braking distances and braking delays in reference to the braking system type and the date of the tram manufacture

\begin{tabular}{|c|c|c|c|c|}
\hline Lp. & Wagon wyprodukowany & Rodzaj hamowania & $\begin{array}{l}\text { Droga hamowania } \\
(\mathrm{m})\end{array}$ & $\begin{array}{c}\text { Opóźnienie } \\
\text { hamowania }\left(\mathrm{m} / \mathrm{s}^{2}\right)\end{array}$ \\
\hline 1 & 2 & 3 & 4 & 5 \\
\hline \multirow{2}{*}{1} & \multirow{2}{*}{ do dnia 31 grudnia $1963 \mathrm{r}$. } & nagle & 17,3 & 2,0 \\
\hline & & robocze lub awaryjne & 43,4 & 0,8 \\
\hline \multirow{3}{*}{2} & \multirow{3}{*}{ po dniu 31 grudnia 1963 r. } & nagłe & 17,3 & 2,0 \\
\hline & & robocze lub awaryjne & 31,5 & 1,1 \\
\hline & & bezpieczeństwa & 34,7 & 1,0 \\
\hline \multirow{3}{*}{3} & \multirow{3}{*}{ po dniu 1 stycznia $2000 \mathrm{r}$. } & nagle & 13,3 & 2,6 \\
\hline & & robocze lub awaryjne & 28,9 & 1,2 \\
\hline & & bezpieczeństwa & 23,1 & 1,5 \\
\hline \multirow{3}{*}{4} & \multirow{3}{*}{ po dniu 1 stycznia 2002 r. } & nagle & 12,4 & 2,8 \\
\hline & & robocze lub awaryjne & 26,7 & 1,3 \\
\hline & & bezpieczeństwa & 23,1 & 1,5 \\
\hline \multirow{3}{*}{5} & \multirow{3}{*}{ po dniu 1 stycznia 2005 r. } & nagle & 11,5 & 3,0 \\
\hline & & robocze lub awaryjne & 24,8 & 1,4 \\
\hline & & bezpieczeństwa & 19,3 & 1,8 \\
\hline
\end{tabular}

Checking the braking performance of the tram parking brake for the type approval must be carried out in accordance with the provisions of Journal of Laws 2011 No. 65 item 344 [2]. The test states that a tram under maximum load, held by the parking brake, should remain stationary on a $5 \%$ slope at minimum. For these tests, the legislator does not impose any methodology for the examination, and therefore the test process remains to be determined by the testing entity.

The remaining braking system checks carried out during the type approval tests are functional and rely only on the confirmation of the correct brake functioning. According to the Journal of Laws 2015 item 38 [1] the tests include:

- brake operation when moving in reverse, where the parking brake should be functional as well as one other brake system, i.e.: service, secondary, or emergency;

- the ability to engage at least the emergency and the parking brakes in the event of the electronic vehicle brake control system failure;

- brake operation in the case of catenary power failure;
Sprawdzenie skuteczności hamowania hamulca postojowego homologowanego tramwaju należy przeprowadzić zgodnie z zapisami w Dz.U. 2011 nr 65 poz. 344 [2]. Badany tramwaj w stanie maksymalnego obciążenia, zahamowany hamulcem postojowym powinien utrzymać się w bezruchu na pochyleniu co najmniej $5 \%$. Dla tych badań ustawodawca nie narzuca żadnej metodyki przeprowadzenia sprawdzenia, a zatem proces badawczy pozostaje do ustalenia przez jednostkę badawczą.

Pozostałe sprawdzenia układu hamulcowego prowadzone podczas badań homologacyjnych mają charakter funkcjonalny i polegają jedynie na potwierdzeniu prawidłowego działania funkcji. Zgodnie z Dz. U. 2015 poz. 38 [1] sprawdzeniu podlega:

- działanie hamulców przy jeździe do tyłu, gdzie powinien działać hamulec postojowy oraz co najmniej jeden rodzaj hamulca tj. roboczy, awaryjny, lub nagły;

- możliwość uruchomienia przynajmniej hamulca awaryjnego oraz postojowego w przypadku awarii sterownika elektronicznego układu nadzorującego proces hamowania pojazdu;

- działanie hamulców w awaryjnych stanach pracy sieci trakcyjnej; 
- operation of the deadman device;

- operation of brakes for moving with open doors;

- the braking system priority over propulsion;

- the function of the rail/wheel grip enhancement device.

In addition, for tram trailer inspection, a functional check of the brake-engagement system is required for when the trailer is disconnected from the tram.

4 ASSESSMENT OF THE EXISTING TRAM TYPE APPROVAL TESTS REQUIREMENTS IN RELATIONS TO THE ACTUAL AND FINAL STATE OF THE BRAKING SYSTEM

Point 3 of this article presents the scope of braking systems tests necessary for the type approval process in Poland. In light of the current design and technical specifications of tram vehicles, the question arises as to whether the requirements for type approval tests listed in the current legal documents give a definitive and reliable picture of the tram braking system.

The first and most important thing is the braking performance. As it is commonly known, the braking distance depends mainly on the speed at which the vehicle is moving when it begins to brake, the braking force generated by the braking system, the weight of the vehicle and, to a lesser extent, on the movement resistance and tracks inclination. The maximum speed for trams currently in production is $70 \mathrm{~km} / \mathrm{h}$, and the expected operating load is over $25 \%$ higher than the tram service mass. As already mentioned, in light of the current type approval regulations, braking tests for all types of brakes at 30 $\mathrm{km} / \mathrm{h}$ and only unloaded vehicles are required. The test results do not answer the question whether the minimum delay criterion that a vehicle must achieve is retained for braking at maximum and intermediate speeds. The applicable regulations do not apply to the maximum delay parameter and the jerk parameter, whose limit values are specified in PN 13452-1 [4], both of which have a significant impact on passenger comfort and safety.

Approval tests conforming to the Polish legislation also do not answer the question whether the characteristic of the brakes is maintained in case of tram load mass corresponding to the number of passengers being carried. Improper characterization of the braking force relative to the mass of the tram, and in the absence of structural dependence of these parameters, results in a decisive increase in braking distance relative to the required values.

As a result, tram type approval regulations should include requirements extending the scope of vehicle braking tests, from the inclusion of maximum and intermediate speeds for braking tests, as well as the mean and maximum loads. The legislator should
- działania urządzenia czuwakowego;

- działania blokady ruszenia $\mathrm{z}$ otwartymi drzwiami;

- nadrzędności funkcji hamowania w stosunku do rozruchu;

- wyposażenie w urządzenie poprawiające współczynnik przyczepności między kołem i szyną.

Dodatkowo w przypadku badań tramwaju doczepnego wymagane jest sprawdzenie funkcjonalne układu włączającego hamulce w chwili odłączenia się tego tramwaju od składu.

\section{OCENA OBOWIAZZUJACYCH WYMAGAŃ} W PROCESIE HOMOLOGACJI TRAMWAJÓW W ODNIESIENIU DO OSTATECZNEGO I WIARYGODNEGO OBRAZU UKLADU HAMULCOWEGO

W punkcie 3 niniejszego artykułu przedstawiono zakres badań koniecznych układów hamulcowych w procesie homologacyjnym tramwajów w Polsce. W świetle obecnie stosowanych rozwiązań konstrukcyjnych i parametrów technicznych pojazdów tramwajowych powstaje pytanie, czy wymagania dotyczące badań homologacyjnych, wymienione w obowiązujących dokumentach prawnych dają ostateczny i wiarygodny obraz układu hamulcowego zastosowanego w tramwaju.

Pierwszą i zasadniczą sprawą jest skuteczność hamowania. Jak wiadomo droga hamowania zależy głównie od prędkości, z jakiej pojazd jest hamowany, siły hamowania generowanej przez układ hamulcowy, masy pojazdu, a także w mniejszym stopniu od oporów ruchu i pochylenia torów. Prędkość maksymalna obecnie budowanych tramwajów sięga najczęściej 70 $\mathrm{km} / \mathrm{h}$, a przewidywane obciążenie eksploatacyjne jest wyższe od masy służbowej tramwaju o ponad $25 \%$. Jak już wspomniano, w świetle obecnych przepisów homologacyjnych wymagane jest sprawdzenie hamowania dla wszystkich rodzajów hamulca z prędkości $30 \mathrm{~km} / \mathrm{h}$ i tylko w stanie bez obciążenia. Wyniki badań nie odpowiadaja na stawiane pytanie, czy kryterium minimalnego opóźnienia, jakie musi osiagnąć pojazd jest zachowane dla hamowania $\mathrm{z}$ prędkości maksymalnej i pośrednich. Obowiązujące przepisy nie odnoszą się także do parametru maksymalnego opóźnienia oraz parametru szarpania, których wartości graniczne precyzuje norma PN-EN 13452-1 [4], które to parametry mają istotny wpływ na komfort i bezpieczeństwo pasażerów.

Badania homologacyjne zgodne $\mathrm{z}$ obwiązująca w Polsce legislacją nie odpowiadają również na pytanie, czy charakterystyka zastosowanych hamulców zachowana jest $\mathrm{w}$ przypadku obciążenia tramwaju masą odpowiadającą liczbie przewożonych pasażerów. Niewłaściwa charakterystyka zależności siły hamowania w stosunku do masy tramwaju, a w gorszym przy- 
also indicate the permissible parameters to be met by the tram track for braking tests i.e. permissible tilt, minimum arc radius, and permissible deviation of the test speed from maximum speed and interpretation of the obtained results, such as braking distance correction requirements taking into account differences in initial speed, deceleration from nominal speed and correction of track inclination to " 0 ". The regulations should also indicate the criteria for the validity of the trials with regard to the reproducibility of the results. These provisions can be based on PN-EN 13452-2 [5] and Annex F of UIC 544-1 [6].

An additional issue with regard to braking performance is the lack of any criteria for braking at reduced wheel and rail grip. The legislature has limited the rules only to the requirement to verify the use of a device that improves the grip coefficient between the wheel and the rail, i.e. sanding machines. The lack of other requirements for slip devices again leaves the brakes at the discretion of the manufacturer and possibly the future operator. Absence of an antilock braking system will cause the wheels to lock in place, resulting in longer braking distance, rolling surface damage (flat seat), and sometimes local track damage. Incorrect operation of the anti-skid system can cause, similarly to the absence of such a system: excessive braking, wheel locking, and, in extreme cases, partial braking loss. Therefore, the legislator should provide a program of motion tests to confirm the correctness and effectiveness of the anti-skid system.

In the present legal state, type approval regulations do not specify the state of the service brake (electrodynamic). According to the division of braking systems as specified in Journal of Laws 2011 No. 65 item 344 [2] secondary brakes serve to stop the tram in the event of a service brake failure and the brake should use brakes independent of the grip between the wheel and the rail. However, this does not specify how one is to determine the failure of the service brake system, resulting in different interpretations among manufacturers.

All sides agree that total elimination of the electrodynamic brake from the service braking system is a state of failure, but not everyone agrees that disabling dynamic braking on one or two bogies must be qualified as a system failure. In some cases, the result is that the loss of dynamic braking on one or two bogies is not sufficiently compensated by another type of brake and therefore the braking distance for the regular and emergency braking is exceeded. Accordingly, the legislator should closely outline the specifications for each brake condition. It should also appropriately classify to which braking state should the braking caused by a deadman or triggered by the "Emergency Brake" button (mushroom button) belong to and be classed as. padku brak uzależnienia konstrukcyjnego tych parametrów, skutkuje zdecydowanym wydłużeniem dróg hamowania w stosunku do wartości wymagdilyedxiązku z powyższym w przepisach dotyczących homologacji tramwajów powinny znaleźć się uregulowania rozszerzające zakres badań o hamowania systemami dostępnymi na pojeździe, z prędkości maksymalnej i prędkości pośrednich oraz dla stanu obciążenia służbowego i maksymalnego. Ustawodawca powinien również wskazać dopuszczalne parametry, jakie powinien spełniać tor tramwajowy dla prowadzenia prób hamowania tj. dopuszczalne pochylenie, minimalny promień łuku, a także dopuszczalne odchylenie prędkości próby od prędkości maksymalnej oraz sposób interpretacji otrzymanych wyników tj. wymagania dotyczące korekty dróg hamowania uwzględniające różnice prędkości początkowej hamowania od prędkości nominalnej oraz korektę pochylenia toru do wartości „,0”. Przepisy powinny również wskazywać kryteria ważności prób w odniesieniu do powtarzalności wyników. Postanowienia te można oprzeć o normę PN-EN 13452-2 [5] i o załącznik F karty UIC 544-1 [6].

Dodatkową kwestią w zakresie skuteczności hamowania jest brak jakichkolwiek kryteriów w przypadku hamowania przy obniżonej przyczepności między kołem a szyną. Ustawodawca ograniczył przepisy jedynie do wymogu sprawdzenia zastosowania na pojeździe urządzenia poprawiającego współczynnik przyczepności między kołem i szyna, tj. piasecznic. Brak innych wymagań odnośnie urządzeń ograniczających poślizg ponownie pozostawia sprawę skuteczności hamulca w gestii producenta i ewentualnie przyszłego eksploatatora. Brak układu przeciwblokującego przy utracie przyczepności spowoduje zablokowanie kół, skutkiem czego będzie wydłużenie drogi hamowania, zniszczenie powierzchni tocznej koła (płaskie miejsce), a niekiedy miejscowe uszkodzenie szyny. Nieprawidłowe parametry pracy układu przeciwpoślizgowego moga powodować, podobnie jak przy braku tego układu, nadmierne wydłużenie drogi hamowania, blokowanie kół, ale także w skrajnym przypadku utratę cześsciowej hamowności. Dlatego ustawodawca powinien przewidzieć program prób ruchowych potwierdzających prawidłowość działania i skuteczność układu przeciwpoślizgowego.

W obecnym stanie prawnym przepisy homologacyjne nie precyzują także kwestii dotyczących stanu awarii hamulca roboczego (elektrodynamicznego). Wg. podziału systemów hamowania zgodnie z Dz.U. $2011 \mathrm{nr} 65$ poz. 344 [2] hamowanie awaryjne służy do zatrzymania tramwaju $\mathrm{w}$ razie awarii hamulca roboczego i hamulec ten powinien wykorzystywać hamulce niezależne od przyczepności między kołem i szyną. Jednak zapis ten nie precyzuje, kiedy mamy do czynienia $\mathrm{z}$ faktycznym stanem awaryjnym, co skutkuje 
Another issue in the study of tram braking systems is the lack of any requirement for the brake operating load. Trams are designed for urban traffic, which is characterized by short distances between stops (stops, junctions). At present, the legislator does not need to provide any evidence that the brake systems maintain the correct parameters under heavy but permissible load.

The last issue that needs to be clarified in terms of type approval tests of tram braking systems is the emergency braking system that is implemented via the passenger brake as well as the braking resulting from the opening of the emergency door. Emergency braking occurs immediately after the passenger pulls the emergency brake handle in the passenger compartment.

The legislator singles out this brake system, assigning the requirements for the maximum braking distance and minimum delay. The activation of the emergency brake deprives the vehicle driver of any influence or control on the vehicle movement. Release of the brake is only possible after unlocking the emergency brake mechanism in the place where it was attached. In normal operation this function of the brake may in extreme cases introduce additional hazard for passengers. Stopping a vehicle in a nondesignated location (such as a tunnel or overpass) can result in, if necessary, obstructing or even the inability to evacuate from a hazardous area. The legislator should, as is the case in railway regulations, propose the introduction of additional safety functions for this brake system, which will allow in the event of an emergency to release the tram emergency brakes from the position of the tram driver and to enable the vehicle to move to a safe location.

The legislator should also clarify the rules for braking the vehicle in the event of an emergency door opening by a passenger. At present, there are no set rules among the manufacturers in how to control the braking system in such case. While the pull of the emergency door lever is treated by everyone as a signal for the implementation of braking, the further effects of this process are different. For some vehicles the service braking system is activated, for others emergency braking, for some vehicles the door can be opened even though the vehicle is still moving; in other cases the lock is removed only after the vehicle comes to a stop. This situation requires that the legislator clearly define what kind of braking should be implemented for emergency door opening. In case of emergency braking it should be possible to release the brakes from the driver's position and bring the vehicle to a safe location before stopping.

\section{CONCLUSIONS}

The current type approval regulations for the braking of tram vehicles are primarily based on the manufacturer's goodwill, reliability and care for the różną jego interpretacją wśród producentów.

Wszyscy są zgodni, że całkowite wyeliminowanie w hamowaniu roboczym hamulca elektrodynamicznego stanowi stan awarii, jednak nie wszyscy zgadzają się z tym, że wyłączenie hamowania dynamicznego na jednym czy dwóch wózkach musi być kwalifikowane jako awaria. W niektórych przypadkach skutkuje to tym, że utrata hamowania dynamicznego na jednym lub dwóch wózkach nie jest dostatecznie kompensowana innym rodzajem hamulca i tym samym zostaje przekroczona droga hamowania dla hamowania roboczego i awaryjnego. W związku z powyższym ustawodawca powinien ściśle sprecyzować wyróżniki dla poszczególnych stanów hamulca. Powinien też odpowiednio zakwalifikować, do którego stanu hamowania należy odnosić hamowania wywołane urządzeniem czuwakowym lub wywoływanym $\mathrm{z}$ przycisku tzw. „hamowania awaryjnego” (przycisk grzybkowy).

Kolejną kwestią w zakresie badań układów hamulcowych tramwajów jest brak jakiegokolwiek wymagania dotyczącego obciążenia eksploatacyjnego hamulca. Pojazdy tramwajowe sa przewidziane do ruchu miejskiego, który charakteryzuje się krótkim dystansami między kolejnymi zatrzymaniami (przystanki, skrzyżowania). W chwili obecnej ustawodawca nie wymaga przedstawienia żadnych dowodów na zachowanie prawidłowych parametrów układu hamulcowego przy dużym obciążeniu tego układu.

Ostatnią kwestia, która wymaga doprecyzowania $\mathrm{w}$ aspekcie badań homologacyjnych układów hamulcowych tramwajów jest system hamowania bezpieczeństwa, który jest wdrażany za pośrednictwem hamulca pasażerskiego, a także hamowania wynikającego z otwarcia awaryjnego drzwi. Hamowanie bezpieczeństwa następuje niezwłocznie po pociagnięciu przez pasażera rączki hamulca bezpieczeństwa umieszczonej w przedziale pasażerskim.

Ustawodawca wyodrębnia ten system hamulca, przypisując mu wymagania w odniesieniu do wartości maksymalnej drogi i minimalnego opóźnienia. Wdrożenie hamulca bezpieczeństwa pozbawia kierującego pojazdem możliwości jakiegokolwiek wpływu na prowadzenie pojazdu. Zwolnienie hamulca jest możliwe dopiero po odblokowaniu mechanizmu hamulca bezpieczeństwa w miejscu, w którym został załączony. W normalnej eksploatacji taki sposób działania tego urządzenia może w skrajnym przypadku wprowadzać dodatkowe niebezpieczeństwo dla pasażerów. Zatrzymanie pojazdu w miejscu do tego nieprzeznaczonym (np. tunel, wiadukt) może skutkować w razie konieczności utrudnieniem lub nawet brakiem możliwości ewakuacji z miejsca zagrożenia. Ustawodawca powinien, podobnie jak ma to miejsce $\mathrm{w}$ przepisach kolejowych, przewidzieć wprowadzenie dodatkowych funkcji bezpieczeństwa dla tego systemu hamulca, które pozwolą w razie niebezpieczeństwa odhamować 
quality of his product and its safety. The end consumer is also able to influence the manufacturer by demanding vehicle's performance to be in accordance with his/her internal company rules and regulations.

It should be stated that this state of affairs is not appropriate. Lack of precise regulations, particularly in safety-sensitive areas, may result in deliberate omissions, such as a desire to reduce the price of a product or the cost of its subsequent exploitation. Limitation of compliance with applicable regulations, where the brake is tested in its narrow range, may result in a reduction not only in comfort but also in the safety of future passengers of the approved vehicle. In light of the current regulations, tram brakes are treated marginally, compared with, for example, lighting, glass or even the door or placement of handrails in the passenger compartment. The provisions in these areas are more precise and the parts used are subject to separate quality tests and must have appropriate certificates, which are not required for the parts and components of the braking systems. Certainly a good direction in the tests of tram braking systems would be to explicitly reference type approval regulations to $\mathrm{PN}-$ EN 13452-1 [1].

\section{BIBLIOGRAPHY LITERATURA}

[1] Dz. U. 2015 poz. 38. Obwieszczenie Ministra Infrastruktury i Rozwoju z dnia 21 listopada 2014 r. $w$ sprawie ogłoszenia jednolitego tekstu rozporzadzenia Ministra Transportu, Budownictwa $i$ Gospodarki Morskiej w sprawie homologacji typu tramwajów i trolejbusów.

[2] Dz. U. nr 65 poz. 344. Rozporzqdzenie Ministra Infrastruktury $z$ dnia 2 marca 2011 r. w sprawie warunków technicznych tramwajów i trolejbusów oraz zakresu ich niezbędnego wyposażenia.

[3] Dz. U. nr 65 poz. 343. Rozporzqdzenie Ministra Infrastruktury z dnia 28 stycznia 2011 r. w sprawie zakresu, warunków, terminów i sposobu przeprowadzania badań technicznych tramwajów $i$ trolejbusów oraz jednostek wykonujacych te badania.

[4] PN-EN 13452-1:2003. Kolejnictwo - Systemy hamowania $w$ transporcie publicznym - Czesść 1: Wymagania eksploatacyjne.

[5] PN-EN 13452-2:2003. Kolejnictwo - Systemy hamowania $w$ transporcie publicznym - Część 2: Metody badań.

[6] UIC 544-1. Wydanie 6. Hamulec-Hamowność.

[7] http://www.hanning-kahl.com

przepisów homologacyjnych do normy PN-EN 13452$1[1]$. tramwaj z pozycji motorniczego i dojechać nim w miejsce bezpieczne.

Ustawodawca powinien również doprecyzować przepisy w zakresie hamowania pojazdu w przypadku awaryjnego otwarcia drzwi przez pasażera. W chwili obecnej panuje wśród producentów pełna dowolność w sterowaniu układem hamulcowym dla takiego stanu. O ile pociagnnięcie dźwigni awaryjnego otwarcia drzwi przez wszystkich traktowane jest jako sygnał wdrożenia hamowania, to dalsze skutki tego procesu są różne. Dla niektórych pojazdów uruchamiany jest system hamowania roboczego, dla innych hamowania awaryjnego, dla niektórych pojazdów drzwi można otworzyć mimo tego, że pojazd jest jeszcze w ruchu, w innych przypadkach blokada zostaje zdjęta dopiero po zatrzymaniu. Opisany stan rzeczy wymaga, aby ustawodawca stanowczo określił, jaki rodzaj hamowania powinien być wdrażany dla funkcji awaryjnego otwarcia drzwi. W przypadku hamowania bezpieczeństwa powinna istnieć możliwość wycofania hamowania z pozycji motorniczego i doprowadzenia pojazdu do bezpiecznego miejsca zatrzymania tramwaju.

\section{PODSUMOWANIE}

Obecnie obowiązujące przepisy homologacyjne w zakresie hamowania pojazdów tramwajowych w głównej mierze opierają się na dobrej woli, rzetelności i dbałości producenta o jakość swojego produktu i bezpieczeństwo jego eksploatacji. Dużą rolę w tej kwestii pełni również przyszły użytkownik, który może wymóc na producencie dochowanie parametrów pojazdu w zależności od swoich wewnętrznych przepisów.

Zdecydowanie trzeba stwierdzić, że taki stan rzeczy nie jest właściwy. Brak precyzyjnych przepisów szczególnie w obszarach decydujących o bezpieczeństwie może doprowadzić do pojawienia się celowych zaniechań wynikających chociażby z chęci obniżenia ceny produktu, a także kosztów jego późniejszej eksploatacji. Ograniczenie się do dochowania standardów wynikających z obowiązujących przepisów, w których hamulec sprawdzony jest $\mathrm{w}$ wąskim zakresie jego pracy, może skutkować obniżeniem nie tylko komfortu, ale także bezpieczeństwa przyszłych pasażerów homologowanego pojazdu. W świetle obecnych przepisów układy hamulcowe pojazdów tramwajowych są traktowane marginalnie, w porównaniu chociażby z kwestiami dotyczącymi oświetlenia, oszklenia czy chociażby drzwi lub rozmieszczenia poręczy w przestrzeni pasażerskiej. Przepisy dotyczące tych dziedzin są bardziej precyzyjne, a stosowane części, aby mogły być zastosowane, podlegają osobnym badaniom i muszą posiadać stosowne świadectwa dopuszczenia, czego nie wymaga się w stosunku do zespołów i części układów hamulcowych. Z pewnością dobrym kierunkiem w badaniach układów hamulcowych tramwajów byłoby jednoznaczne odwołanie 